Krystyna Janicka, Kazimierz M. Słomczyński

IFiS PAN

Uniwersytet Zielonogórski

\title{
OD NIERÓWNOŚCI DO POLARYZACJI: BIEGUNOWOŚĆ STRUKTURY KLASOWEJ A RÓŻNICE W POSTAWACH NATURY SPOLECZNEJ I POLITYCZNEJ
}

\section{WPROWADZENIE}

Jednym z podstawowych problemów z zakresu badań nad strukturą społeczną jest kwestia wzajemnych relacji między strukturą klasową a układem nierówności czyli uwarstwieniem społecznym. Wychodząc od koncepcji klasy społecznej jako zmiennej nominalnej, zamierzamy skupić się na relacjach łączących przynależność do klasy z usytuowaniem w wielowymiarowo definiowanym układzie nierówności. Podejmując ten problem nawiązujemy do wciąż aktualnej w socjologii debaty na temat realności klas społecznych.

Odwołując się do analiz prezentowanych w naszych wcześniejszych publikacjach, w artykule przedstawiamy w sposób dynamiczny przemiany struktury klasowej od 1988 r. i wskazujemy na postępujące rozwarstwienie według formalnego wykształcenia, statusu zawodowego i dochodu na głowę. Dystans dzielący bogatych przedsiębiorców od ludzi biednych rośnie w wyniku dwóch procesów: koncentracji kapitału i postępującej pauperyzacji oraz ich strukturalnych konsekwencji. Procesy te odzwierciedlają prawo św. Mateusza, które w uproszczonej wersji mówi, iż ci co mają dużo będą mieli jeszcze więcej, a ci, co mają mało będą mieli jeszcze mniej.

W Polsce wzrastające obiektywne nierówności społeczne przebiegają w płaszczyźnie klasowej. Pytanie jednak zachodzi, czy działanie prawa św. Mateusza znajduje swe przedłużenie w polaryzacji społecznej polegającej na powstawaniu przeciwstawnych sobie obozów w sprawach natury społecznej i politycznej. Poruszając się w tak określonej przestrzeni społecznej pokażemy klasowy charakter mechanizmów dystrybucyjnych dóbr przesądzających o osiągniętej pozycji społecznej, a także korelaty psychologiczne współgrające z położeniem klasowym. Nasze analizy wskazują, że w polskim społeczeństwie ma miejsce polaryzacja grup społecznych ze względu na postawy wobec zasad gospodarki kapitalistycznej. 
Twierdzimy przy tym, że proces ten jest ściśle powiązany z przynależnością klasową co oznacza, że klasy mają realny wpływ na poglądy ludzi. Przewidując na tej podstawie przyszłe losy społeczeństwa polskiego należałoby spodziewać się pogłębienia rozwarstwienia społecznego prowadzącego aż do pęknięcia struktury społecznej oraz towarzyszącego tym procesom nasilenia konfliktowości.

Aby odpowiedzieć na stawiane pytania badawcze sięgamy do danych Polskiego Surveyu Panelowego 1988-2008 (POLPAN). W badaniach te same osoby udzielały wywiadu w latach 1988, 1993, 1998, 2003 i 2008. Badania przeprowadzał Instytut Filozofii i Socjologii PAN, a w szczególności sekcja realizacji badań terenowych. W 1988 roku próba obejmowała reprezentację mężczyzn i kobiet $\mathrm{w}$ wieku 21-65 lat. Niektóre $\mathrm{z}$ analiz przedstawione $\mathrm{w}$ tym artykule zostały wykonane na materiałach uwzględniających dodatkowo podpróby osób młodszych, w wieku 21-30 w 1998 r. i 21-25 w latach 2003 i 2008. Próba z 2008 r. jest reprezentatywna dla dorosłej ludności Polski.

\section{KLASY SPOLECZNE I ICH HIERARCHIZACJA}

Struktura społeczna stanowi układ kategorii i grup ludności oraz instytucjonalne ramy dla ich funkcjonowania. W strukturze społecznej, w wyniku radykalnych zmian ekonomicznych i politycznych, powstają różnorakie naprężenia. Nieciągłości ewolucyjne mogą powodować, że układ kategorii i grup ludności staje się źle dostosowany do swojego otoczenia, czyli do warunków zewnętrznych. Nawiązując do wcześniejszych publikacji, na określenie takiego stanu używamy metaforycznego języka i wskazujemy na pęknięcia w strukturze społecznej, które odzwierciedlają procesy polaryzacji ${ }^{1}$.

Z socjologicznego punktu widzenia, kluczem do analizy struktury społecznej była i jest struktura klasowa jako podstawa nierówności społecznych. Przez klasy społeczne rozumiemy tutaj grupy, które w różnych wymiarach i w różnym stopniu kontrolują społeczne zasoby istotne w funkcjonowaniu rynku kapitału, rynku pracy i rynku konsumpcji. Kontrola środków produkcji i usług poprzez własność, kontrola procesu pracy poprzez kwalifikacje kierownicze i zawodowe, oraz dysponowanie środkami finansowymi, które mogą być przeznaczone na nabycie pożądanych dóbr są istotnymi kryteriami podziałów klasowych.

${ }^{1}$ Przytaczamy tu następujące prace: Polarized Social-Class Structure: On the Matthew Effect and Increasing Inequality (Słomczyński i Janicka 2008 i wcześniejsza wersja 2005), Changes in Class Structure in Poland, 1988-2003: Crystallization of the Winners-Loosers 'Divide (Słomczyński, Janicka, Shabad i Tomescu-Dubrow 2007) oraz Systemowe zmiany w strukturze klasowej a ruchliwość społeczna. Analiza tablic przepływu osób między różnymi kategoriami początkowymi i końcowymi (Słomczyński i Tomescu-Dubrow 2009). 
W badaniach POLPAN wychodzimy z założenia, że struktura klasowa w okresie gospodarki realnego socjalizmu różniła się w istotny sposób od struktury klasowej rodzącego się kapitalizmu. Przyjmując tę ogólną przesłankę zakładamy, że struktura klasowa w Polsce powinna być ujmowana dynamicznie i odzwierciedlać specyfikę transformacji ustrojowej. Konstytutywnymi stosunkami społecznymi klas są stosunki własności (posiadanie kapitału, który sytuuje jednostkę wobec innych jednostek jako faktycznego lub potencjalnego pracodawcę), stosunki kontroli procesu pracy (w szczególności bycie menedżerem lub kierownikiem umożliwia jednostce zarządzanie czasem innych jednostek) oraz stosunki dominacji konsumpcyjnej (kumulacja pewnych dóbr umożliwia wytwarzanie zależności interpersonalnych). Ogólnie rzecz biorąc, stosunki te są realizowane na rynku kapitału, rynku pracy, oraz rynku dóbr i usług. Jeżeli dane formy rynków są słabo rozwinięte - jak na przykład rynek kapitału w socjalizmie - inne instytucje, w tym polityczne, pełnią role zastępcze. W każdym razie stosunki własności, kontroli pracy i dominacji konsumpcyjnej są podstawą do formowania się klas społecznych, a ów proces polega również na tym, że jednostki czują swoją odrębność i uzyskują identyfikację społeczno-kulturową.

Od dawna przyjmowana konceptualizacja struktury klasowej społeczeństwa socjalistycznego opiera się na założeniu, że kontrola życia ekonomicznego przez aparat partyjny i państwowy zmniejsza wagę tradycyjnie używanego kryterium wyodrębniania klas społecznych: własności środków produkcji. Jednakże społeczeństwa realnego socjalizmu posiadały dobrze zdefiniowane charakterystyki strukturalne - takie, jak nap. system nomenklatury pozwalający na nakazowo-rozdzielczą kontrolę zasobów ekonomicznych, czy wielkoprzemysłową klasę robotniczą, początkowo występującą jedynie jako symbol industrializacji, ale później jako istotna siła polityczna. Uważamy więc, iż strukturę klasową centralnie zarządzanego społeczeństwa socjalizmu państwowego trafnie charakteryzowały następujące kategorie: nomenklatura wyróżniona na podstawie kryterium politycznego i stanowiąca około 3,5\% pracujących, szeroko rozumiana inteligencja, czasem określana warstwą $(36,7 \%)$, wiekoprzemysłowa klasa robotnicza, zwana też trzonem klasy robotniczej (28,3\%), peryferyjna klasa robotnicza, zawierająca też nisko wykwalifikowane pozycje w usługach $(8,8 \%)$, chłopstwo $(18,3)$ oraz inicjatywa prywatna.

Poczynając od 1989 r., zmiany w strukturze klasowej wyrażały się nie tylko w przekształceniach jej „starych” elementów, ale także w powstaniu „nowych", głównie jako wynik procesów demokratyzacji i wprowadzenia zasad rynkowych. Kiedy rozpatrujemy ,stare” elementy struktury klasowej warto uzmysłowić sobie ogrom zmian, jakie zaszły po upadku realnego socjalizmu. 
Na przykład, aczkolwiek ze względu na kryterium własności ziemi klasa chłopska pozostaje nadal tą samą klasą, ale ze względu na powiązanie z wolnym rynkiem produktów rolnych - jest już klasą inną, klasą rolników. Nowe klasy obejmują przedsiębiorców - właścicieli firm zatrudniających siłę roboczą - czy „kapitanów kapitalizmu” - menedżerów na wolnym rynku. Na wstępie zaznaczamy tylko, iż interesują nas przekształcenia układu klas socjalistycznych do układu klas kapitalistycznych.

W nowych warunkach ustrojowych, po 1989 r., konstytutywnym kryterium klasowości stała się własność środków produkcji, a wzrosło znaczenie kontroli organizacyjnej nad pracą innych oraz zasobów i kompetencji w zakresie wiedzy teoretycznej i praktycznej. Biorąc pod uwagę wielkość kapitału, zatrudnienie pracowników oraz poziom zarządzania, a także poziom kwalifikacji i umysłowy lub fizyczny charakter pracy, w strukturze klasowej społeczeństwa postkomunistycznego jako nowe kategorie wyodrębniono: przedsiębiorców (oddzielając ich od pracujących na własny rachunek), menedżerów (jako zarządców firm z dużą autonomią) i ekspertów (specjalistów, którzy w nowym systemie pełnią inne role niż w systemie komunistycznym). Wyodrębniono również techników i pracowników biurowych jako odpowiednik kategorii (i klasy społecznej), która pasuje do gospodarki kapitalistycznej i określana jest mianem semiprofessionals. Robotnicy, bez względu na dział zatrudnienia, zostali potraktowani łącznie, ponieważ - w wyniku odejścia od centralnego planowania - osłabieniu uległ podział na pracowników produkcyjnych i nieprodukcyjnych. Jednakże wzrosła rola kwalifikacji i w związku z tym uwzględniamy podział na robotników wykwalifikowanych i niewykwalifikowanych.

Musimy także założyć, że rola tych samych kategorii klasowych zmienia się w czasie. Mając te zmiany na myśli, dla okresu transformacji postkomunistycznej i budowy kapitalizmu wykorzystujemy tu następujący schemat kategorii klasowych:

1. Przedsiębiorcy, do których zaliczamy tylko te osoby, które posiadają własną firmę i zatrudniają siłę roboczą poza własną rodziną. Jest to kategoria, która faktycznie powstała w procesie transformacji post-komunistycznej. W epoce socjalizmu stosunkowo nieliczni przedsiębiorcy, którzy zatrudniali siłę roboczą zwykle byli zaliczani razem z samodzielnymi pracownikami do inicjatywy prywatnej.

2. Menedżerowie, którzy oznaczają tu wyższe kadry kierownicze w zakładach produkcyjnych i usługowych, a także wyższe kadry administracyjne. W socjalizmie - a więc do 1989 r. - kategoria ta odpowiada klasie dysponentów mienia publicznego. W okresie transformacji postkomunistycznej jest to elita zarządzająca instytucjami państwowymi i prywatnymi. 
3. Eksperci są kategorią skupiającą tych wszystkich, którzy pracują w zawodach wymagających przygotowania na poziomie wykształcenia wyższego. Tradycyjnie są to górne warstwy inteligencji. Chociaż rola tej klasy uległa zmianie w czasie aksamitnej rewolucji 1989 r. i w procesie ewolucji systemu ekonomicznego i politycznego, jej cechą wyróżniającą są kwalifikacje.

4. Kierownicy, czyli bezpośredni kontrolerzy procesu pracy. Są to kierownicy najmniejszych zespołów roboczych, którzy zwykle nadzorują pracę od 2 do 25 osób. To, co ich odróżnia od menedżerów, to ograniczenie ich władzy do jednej sfery: procesu pracy.

5. Samodzielni - pracujący na własny rachunek. Są to ci właściciele warsztatów pracy, którzy nie zatrudniają - poza rodziną - siły roboczej. W socjalizmie stanowili oni trzon prywatnej inicjatywy i byli względnie homogeniczną grupą rzemieślników, a także drobnych producentów i kupców. W wyniku postkomunistycznej transformacji, grupa ta stała się wewnętrznie zróżnicowana i to z niej wyodrębniła się klasa przedsiębiorców.

6. Wykonawczy pracownicy umysłowi. Konieczność znacznego wysiłku mentalnego w procesie pracy jest kryterium pozwalającym odróżnić wykonawczych pracowników umysłowych od pracowników fizycznych. Jednakże wykonawczy pracownicy umysłowi - tak, jak tu są rozumiani - nie obejmują ekspertów, którzy stanowią odrębną kategorię klasową.

7. Wykwalifikowani pracownicy fizyczni. Są to przede wszystkim robotnicy fabryczni. W czasach socjalizmu byli oni nazywani awangardą klasy robotniczej, ale ich rola w procesie postkomunistycznej transformacji uległa zasadniczej zmianie, szczególnie w przemyśle ciężkim.

8. Niewykwalifikowani pracownicy fizyczni są pracownikami, których w zasadzie można przyuczyć do wykonywania czynności roboczych w stosunkowo krótkim czasie, na ogół nie dłuższym niż pół roku. Znaczna część tych pracowników pracuje w usługach, przy prostych pracach.

9. Rolnicy. Jest to kategoria bardzo zróżnicowana pod względem kwalifikacji i zamożności, ale to co ich łączy, to posiadanie i uprawianie ziemi. W okresie socjalizmu, rolnicy byli w dużym stopniu zależni od państwa, ze względu na zakup sprzętu i innych środków produkcji, a także ze względu na kontrakty na rolniczą produkcję. W okresie transformacji postkomunistycznej, konkurencja rolnych produktów zachodnich stała się istotnym problemem dla polskich rolników.

Biorąc pod uwagę wielowymiarowość interesów i ich jakościowe zróżnicowanie, klasy społeczne są bytami (obiektami) najwyżej częściowo uporządkowanymi. Na przykład, w wymiarze władzy kierownicy plasują się oczywiście znacznie „wyżej” niż pracownicy biurowi i technicy, ale trudno jest orzec, jaka 
jest ich pozycja w stosunku do przedsiębiorców lub osób prowadzących działalność gospodarczą na własny rachunek. Analogiczne trudności z hierarchizacją klas pojawiają się przy innych kryteriach definicyjnych - np. charakterze pracy. Bezpieczniej jest zatem traktować klasy społeczne jako zmienną nominalną niż zmienną porządkową.

Ustalenia hierarchizacji klas społecznych - od uplasowanych na górze do uplasowanych na dole drabiny społecznej - wymaga odwołania się do kryteriów zewnętrznych: cech położenia społecznego. Chodzi tu przede wszystkim o dostęp do oświaty (w postaci uzyskiwanego wykształcenia), rodzaj pracy (w szczególności jej złożoność) i położenie materialne (np. dochód gospodarstwa domowego). Trzy wymiary - edukacyjny, zawodowy i ekonomiczny - są często traktowane jako podstawa systemu stratyfikacyjnego nowoczesnych społeczeństw.

Tak więc podstawowym kryterium zewnętrznym hierarchizacji klas społecznych jest ich miejsce w systemie stratyfikacji społecznej. Formalne wykształcenie, status zawodowy i faktyczny dochód są trzema wskaźnikami położenia jednostek w strukturze społecznej, które powszechnie uważa się za fundament systemu stratyfikacyjnego współczesnych społeczeństw. W sensie statystycznym przynależność jednostek do klas społecznych i pozycja stratyfikacyjna - zwykle wyrażona jako zmienna interwałowa - są ze sobą związane. Jednakże siła tego związku zależy od miejsca i czasu, podlegając długoterminowym trendom i chwilowym wahaniom. Pytanie, w jakim stopniu klasy społeczne różnią się między sobą pod względem zmiennych stratyfikacyjnych w różnych fazach przekształceń społecznych jest pytaniem ważnym teoretycznie i praktycznie.

Zastosujemy tutaj standardową metodę wyrażania pozycji stratyfikacyjnej jako liniowej kombinacji formalnego wykształcenia, pozycji zawodowej i zarobków. Wykształcenie mierzone jest jako przybliżona liczba lat szkolnych przy założeniu, że niepełnemu wykształceniu podstawowemu przyporządkowana jest liczba 5 lat, podstawowemu pełnemu - 8 lat, zasadniczemu zawodowemu lub niepełnemu średniemu -10 lat, średniemu ogólnemu lub zawodowemu -12 lat, niepełnemu wyższemu -14 lat, wyższemu pełnemu 17 lat. Pozycja zawodowa mierzona jest na skali społeczno-ekonomicznej, która każdej z 375 podstawowych jednostek zawodowych Społecznej Klasyfikacji Zawodów przyporządkowuje specyficzne wartości². Zarobki odnoszą się do całkowitego dochodu respondenta $\mathrm{w}$ stałych złotych, przeliczonych według indeksu średnich rzeczywistych dochodów i wynagrodzeń miesięcznych brutto.

\footnotetext{
${ }^{2}$ Społeczna Klasyfikacja Zawodów i dostosowane do niej skale zawodów omówione są w pracy Domańskiego, Sawińskiego i Słomczyńskiego (2007).
} 
W modelach pomiarowych, które opracowaliśmy dla okresu 1988-2008, pozycja w hierarchii stratyfikacji społecznej rozumiana jest jako konstrukt złożony, w którym formalne wykształcenie, pozycja zawodowa oraz dochody są podstawowymi wskaźnikami. W procedurze pomiarowej jest rzeczą przydatną ocenić stopień zgodności pomiędzy składnikami ogólnej pozycji stratyfikacyjnej. Związek pomiędzy składnikami wyrażający zgodność odpowiada pierwszemu wymiarowi analizy czynnikowej formalnego wykształcenia, pozycji zawodowej i zarobków z pracy. Ponieważ korelacje pomiędzy tymi zmiennymi są dodatnie, przeto wagi czynnikowe również muszą być dodatnie. W konsekwencji, związek pomiędzy wskaźnikami oraz wyodrębnionym czynnikiem jest jednoznacznie interpretowalny: im wyższe jest formalne wykształcenie, pozycja zawodowa oraz dochody danej jednostki, tym wyższa jest jej pozycja stratyfikacyjna. Ta zależność odpowiada pojęciu „wymiaru wertykalnego” stratyfikacji społecznej.

W tabeli 1 określone zostały związki pomiędzy formalnym wykształceniem, pozycją zawodową i dochodami. W wymiarze ogólnego statusu - pozycji stratyfikacyjnej - zmiany te dotyczą przede wszystkim roli zarobków. Jednakże struktura czynnikowa jest zbliżona dla całego dwudziestolecia 1988-2008.

Tabela 1. Formalne wykształcenie, pozycja zawodowa i zarobki jako składowe ogólnego statusu oraz elementy (analiza czynnikowa) rozbieżności czynników statusu w latach 1988-2008

\begin{tabular}{|l|c|c|c|c|c|}
\hline \multirow{2}{*}{\begin{tabular}{c}
\multirow{2}{*}{$\begin{array}{c}\text { Położenie społeczne i jego } \\
\text { składowe }\end{array}$} \\
\cline { 2 - 7 }
\end{tabular}} & 1988 & 1993 & 1998 & 2003 & 2008 \\
\cline { 2 - 6 } \multicolumn{7}{c|}{ Ogólny status - pozycja stratyfikacyjna } \\
\hline Formalne wykształcenie & 0,910 & 0,912 & 0,907 & 0,895 & 0,859 \\
\hline Pozycja zawodowa & 0,909 & 0,896 & 0,901 & 0,827 & 0,879 \\
\hline Zarobki & 0,449 & 0,499 & 0,469 & 0,612 & 0,657 \\
\hline Wartość własna & 1,854 & 1,883 & 1,854 & 1,860 & 1,943 \\
\hline Proporcja wyjaśnionej wariancji & 0,619 & 0,628 & 0,618 & 0,620 & 0,648 \\
\hline
\end{tabular}

Źródło: badania POLPAN 1988-2008 (dotyczy tab. 1-5).

Aby klasy społeczne były w istocie ważnymi kategoriami struktury społecznej, muszą być spełnione dwa konieczne i wystarczające warunki, które dotyczą:

- rozkładu średnich: klasy społeczne różnią się znacznie pod względem przeciętnych wartości ważnych cech położenia społecznego (warunek 1); 
- rozkładu wariancji: zróżnicowanie wartości ważnych cech położenia społecznego jest istotnie większe między klasami niż zróżnicowanie wewnątrz klas (warunek 2).

W tabeli 2 zawarte zostały dane świadczące, iż oba warunki są spełnione zarówno dla schyłku socjalizmu (1988 r.), jak i już rozwiniętego kapitalizmu (2008 r.). W pierwszym okresie, układ klas według ogólnej pozycji stratyfikacyjnej wskazuje, iż nomenklatura, pracownicy umysłowi i inicjatywa prywatna znajduje się powyżej, a wielkoprzemysłowa klasa robotnicza, peryferyjna klasa robotnicza i chłopi poniżej przeciętnej dla całej populacji. Jest to typowa hierarchia dla tamtego okresu. Współczynnik eta ${ }^{2}$, będący miarą związku pomiędzy przynależnością klasową a ogólnym statusem społecznym, miał wysoką i statystycznie znaczącą wartość $(0,581)$. Oznacza to, że zastosowane kryteria przynależności klasowej odgrywały istotną rolę w nierównej dystrybucji społecznie pożądanych dóbr. Istotnie, w tamtym okresie korelacje pomiędzy klasą społeczną a statusem i jego elementami - wykształceniem, zawodem i dochodem - były nie mniejsze niż odpowiednie korelacje na Zachodzie.

Tabela 2. Średnia wartość ogólnego statusu i jego składowych dla klas społecznych w okresie schyłkowym socjalizmu (1988) i rodzącego się kapitalizmu (2008)

\begin{tabular}{|c|c|c|c|c|}
\hline \multirow{3}{*}{ Klasa społeczna } & \multirow{2}{*}{$\begin{array}{c}\text { Ogólny status } \\
\text { (pozycja stra- } \\
\text { tyfikacyjna) }\end{array}$} & \multicolumn{3}{|c|}{ Składowe ogólnego statusu } \\
\hline & & $\begin{array}{c}\text { formalne } \\
\text { wykształcenie }\end{array}$ & $\begin{array}{c}\text { pozycja } \\
\text { zawodowa }\end{array}$ & zarobki \\
\hline & \multicolumn{4}{|c|}{$\begin{array}{c}\text { Średnia wartość w jednostkach standaryzowanych }(\mu=0, \sigma=1) \\
\text { (wewnątrzklasowe dchylenie standardowe) }\end{array}$} \\
\hline 1 & 2 & 3 & 4 & 5 \\
\hline \multicolumn{5}{|c|}{ A. 1988} \\
\hline Nomenklatura & $\begin{array}{c}1,624 \\
(0,654)\end{array}$ & $\begin{array}{c}1,548 \\
(0,699)\end{array}$ & $\begin{array}{c}1,754 \\
(0,267)\end{array}$ & $\begin{array}{l}1,475 \\
(0,987)\end{array}$ \\
\hline $\begin{array}{l}\text { Wykonawczy pracownicy } \\
\text { umysłowi }\end{array}$ & $\begin{array}{c}0,407 \\
(0,341)\end{array}$ & $\begin{array}{c}0,618 \\
(0,583)\end{array}$ & $\begin{array}{c}0,512 \\
(0,478)\end{array}$ & $\begin{array}{c}0,086 \\
(0,384)\end{array}$ \\
\hline $\begin{array}{l}\text { Wielkoprzemysłowa klasa } \\
\text { robotnicza }\end{array}$ & $\begin{array}{l}-0,302 \\
(0,601)\end{array}$ & $\begin{array}{l}-0,453 \\
(0,657)\end{array}$ & $\begin{array}{l}-0,206 \\
(0,340)\end{array}$ & $\begin{array}{l}-0,159 \\
(0,211)\end{array}$ \\
\hline Peryferia klasy robotniczej & $\begin{array}{l}-0,744 \\
(, 0435)\end{array}$ & $\begin{array}{l}-0,573 \\
(0,641)\end{array}$ & $\begin{array}{l}-0,726 \\
(0,321)\end{array}$ & $\begin{array}{l}-0,498 \\
(0,640)\end{array}$ \\
\hline Chłopi & $\begin{array}{l}-0,892 \\
(0,503)\end{array}$ & $\begin{array}{l}-0,578 \\
(0,430)\end{array}$ & $\begin{array}{l}-0,975 \\
(0,567)\end{array}$ & $\begin{array}{l}-0,458 \\
(0,507)\end{array}$ \\
\hline $\begin{array}{l}\text { Samodzielni (pracujący } \\
\text { na własny rachunek) }\end{array}$ & $\begin{array}{c}0,101 \\
(0,711)\end{array}$ & $\begin{array}{c}0,259 \\
(0,759)\end{array}$ & $\begin{array}{c}0,194 \\
(0,488)\end{array}$ & $\begin{array}{c}0,360 \\
(0,518)\end{array}$ \\
\hline Wspótczynnik eta ${ }^{2}$ & 0,581 & 0,554 & 0,670 & 0,239 \\
\hline
\end{tabular}


Od nierówności do polaryzacji...

\begin{tabular}{|c|c|c|c|c|}
\hline 1 & 2 & 3 & 4 & 5 \\
\hline \multicolumn{5}{|c|}{ B. 2008} \\
\hline $\begin{array}{l}\text { Przedsiębiorcy (zatrudniający } \\
\text { siłę roboczą) }\end{array}$ & $\begin{array}{c}0,872 \\
(0,758)\end{array}$ & $\begin{array}{c}0,611 \\
(0,913)\end{array}$ & $\begin{array}{c}0,443 \\
(0,132)\end{array}$ & $\begin{array}{c}1,558 \\
(1,462)\end{array}$ \\
\hline $\begin{array}{l}\text { Menedżerowie (wyższe kadry } \\
\text { kierownicze) }\end{array}$ & $\begin{array}{c}1,359 \\
(0,960)\end{array}$ & $\begin{array}{c}1,379 \\
(0,798)\end{array}$ & $\begin{array}{c}1,221 \\
(0,940)\end{array}$ & $\begin{array}{c}0,977 \\
(1,366)\end{array}$ \\
\hline Eksperci (specjaliści) & $\begin{array}{l}1,548 \\
(0,412)\end{array}$ & $\begin{array}{c}1,872 \\
(0,405)\end{array}$ & $\begin{array}{c}1,892 \\
(0,680)\end{array}$ & $\begin{array}{c}0,481 \\
(0,520)\end{array}$ \\
\hline $\begin{array}{l}\text { Kierownicy (bezpośredni kon- } \\
\text { trolerzy procesu pracy) }\end{array}$ & $\begin{array}{c}0,644 \\
(0,914)\end{array}$ & $\begin{array}{c}0,654 \\
(0,968)\end{array}$ & $\begin{array}{c}0,815 \\
(0,971)\end{array}$ & $\begin{array}{c}0,518 \\
(0,928)\end{array}$ \\
\hline $\begin{array}{l}\text { Samodzielni (pracujący } \\
\text { na własny rachunek) }\end{array}$ & $\begin{array}{c}0,013 \\
(0,871)\end{array}$ & $\begin{array}{c}0,332 \\
(1,036)\end{array}$ & $\begin{array}{l}-0,373 \\
(0,614)\end{array}$ & $\begin{array}{r}0,639 \\
(1,673)\end{array}$ \\
\hline $\begin{array}{l}\text { Wykonawczy pracownicy } \\
\text { umysłowi }\end{array}$ & $\begin{array}{l}-0,109 \\
(0,662)\end{array}$ & $\begin{array}{c}0,310 \\
(0,764)\end{array}$ & $\begin{array}{l}-0,015 \\
(0,802)\end{array}$ & $\begin{array}{l}-0,372 \\
(0,390)\end{array}$ \\
\hline $\begin{array}{l}\text { Wykwalifikowani pracownicy } \\
\text { fizyczni }\end{array}$ & $\begin{array}{l}-0,690 \\
(0,290)\end{array}$ & $\begin{array}{l}-0,510 \\
(0,429)\end{array}$ & $\begin{array}{l}-0,547 \\
(0,429)\end{array}$ & $\begin{array}{l}-0,291 \\
(0,359)\end{array}$ \\
\hline $\begin{array}{l}\text { Niewykwalifikowani pracown- } \\
\text { icy fizyczni }\end{array}$ & $\begin{array}{l}-0,999 \\
(0,303)\end{array}$ & $\begin{array}{l}-0,483 \\
(0,576)\end{array}$ & $\begin{array}{l}-1,089 \\
(0,107)\end{array}$ & $\begin{array}{l}-0,641 \\
(0,210)\end{array}$ \\
\hline Rolnicy & $\begin{array}{l}-0,733 \\
(0,411) \\
\end{array}$ & $\begin{array}{l}-0,522 \\
(0,555)\end{array}$ & $\begin{array}{l}-0,557 \\
(0,108)\end{array}$ & $\begin{array}{l}-0,389 \\
(0,792)\end{array}$ \\
\hline Współczynnik eta ${ }^{2}$ & 0,632 & 0,548 & 0,623 & 0,318 \\
\hline
\end{tabular}

W tabeli 2 przedstawiono także układ klas po dokonaniu transformacji postkomunistycznej (2008 r.). Menedżerowie, eksperci i przedsiębiorcy ulokowani są na górze drabiny społecznej. Pracownicy fizyczni - wykwalifikowani i niewykwalifikowani - oraz rolnicy lokują się na dole drabiny społecznej. Dystans między „górą" a „dołem” jest bardzo duży - średnio przekracza dwa i pół odchylenia standardowego standaryzowanych jednostek. Współczynnik eta ${ }^{2}$ przybiera wyższą wartość niż w 1988 r. (0,632 w porównaniu z 0,581). Jednakże porównanie wartości współczynników eta ${ }^{2}$ dla składowych ogólnej pozycji statyfikacyjnej wskazuje, iż polaryzacja klasowa dokonała się głównie za sprawą znacznie zwiększonych różnic dochodowych.

\section{KLASY SPOLECZNE A ADAPTACJA DO NOWEGO SYSTEMU}

Według różnych teorii przemian struktury społecznej w społeczeństwach postkomunistycznych klasowe uwarunkowania opinii publicznej powinny być szczególnie wyraźne w odniesieniu do zasad funkcjonowania gospodarki 
kapitalistycznej. Ponieważ teoria kapitalizmu jest w pewnym sensie teorią wolnego rynku, przyjmujemy tutaj, że podstawą funkcjonowania gospodarki kapitalistycznej jest właśnie wolny rynek - zarówno kapitału, jak i pracy czy dóbr konsumpcyjnych. Powstaje więc pytanie, w jakim stopniu klasy społeczne różnią się między sobą w zakresie poparcia dla różnych instytucji rynku. Odpowiedź na to pytanie jest ważna ze względu na podstawową tezę tego rozdziału o pogłębianiu się różnic między klasami społecznymi.

W naszych badaniach panelowych respondenci byli pytani o to: (1) czy zgadzają się z prywatyzacją państwowych zakładów pracy, nawet gdy przynoszą one dochód (rynek kapitału), (2) w jakim stopniu uważają, że państwo powinno zapewnić pracę każdemu, kto chce ją podjąć (rynek pracy), oraz (3) w jakim stopniu uważają, że ceny żywności powinny być pod kontrolą państwa (rynek dóbr). Poparcie dla rozwiązań wolnorynkowych oznacza zgodę na prywatyzację i względnie silną opozycję wobec roli państwa jako dostarczyciela pracy i kontrolera cen. Na podstawie odpowiedzi na pytania dotyczące zgody na prywatyzację oraz sprzeciwu wobec państwowej kontroli zatrudnienia i cen skonstruowaliśmy zbiorczy indeks mierzący postawy prorynkowe ${ }^{3}$.

$\mathrm{Na}$ wykresie 1 przedstawiono społeczne zróżnicowanie tych postaw dla 2003 r. Klasy społeczne, które określane są tu mianem „Zwycięzców transformacji” - menedżerowie, eksperci, przedsiębiorcy - zdecydowanie przejawiają najsilniejsze postawy prorynkowe. Na dole hierarchii społecznej obserwujemy najsilniejszą opozycję wobec rozwiązań popierających wolny rynek. Przepaść między „górą" a „dołem” hierarchii jest w tym zakresie bardzo duża, średnio przekracza jedno odchylenie standardowe. Wyniki dla 2008 r. w zasadzie nie różnią się od tych tu przedstawionych.

W układzie dynamicznym w tabeli 3 przedstawiamy dane, które mamy dla wszystkich dotychczasowych fal panelu. Są to dane dotyczące pytania, w jakim stopniu państwo powinno zapewnić pracę każdemu, kto chce ją podjąć. W latach 1988-2008 proporcja osób opowiadających się za tym, aby państwo zapewniało pracę każdemu, kto chce ją podjąć zmalała drastycznie: od 70,5\% do 46,6\%. Wśród klas uprzywilejowanych spadek procentowy jest monotoniczny, z przeszło dwudziestoprocentową różnicą między latami 1988 i 1993, znacznie mniejszymi różnicami w latach następnych, aby w 2008 r. osiągnąć wartość 24,9\%. Na dole hierarchii różnice procentowe między latami są mniejsze i obserwuje się pewną fluktuację w dziesięcioleciu 1993-2003. Wszakże w tej kategorii respondentów spadek procentowy między latami 1988 i 2008 jest znaczny, od $70,9 \%$ do $55,1 \%$.

${ }^{3} \mathrm{~W}$ tym celu posłużyliśmy się analizą czynnikową. Odpowiedzi na każde z pytań miały ładunek czynnikowy większy niż 0,6; procent wyjaśnionej wariancji wyniósł 64,5. 
Od nierówności do polaryzacji...

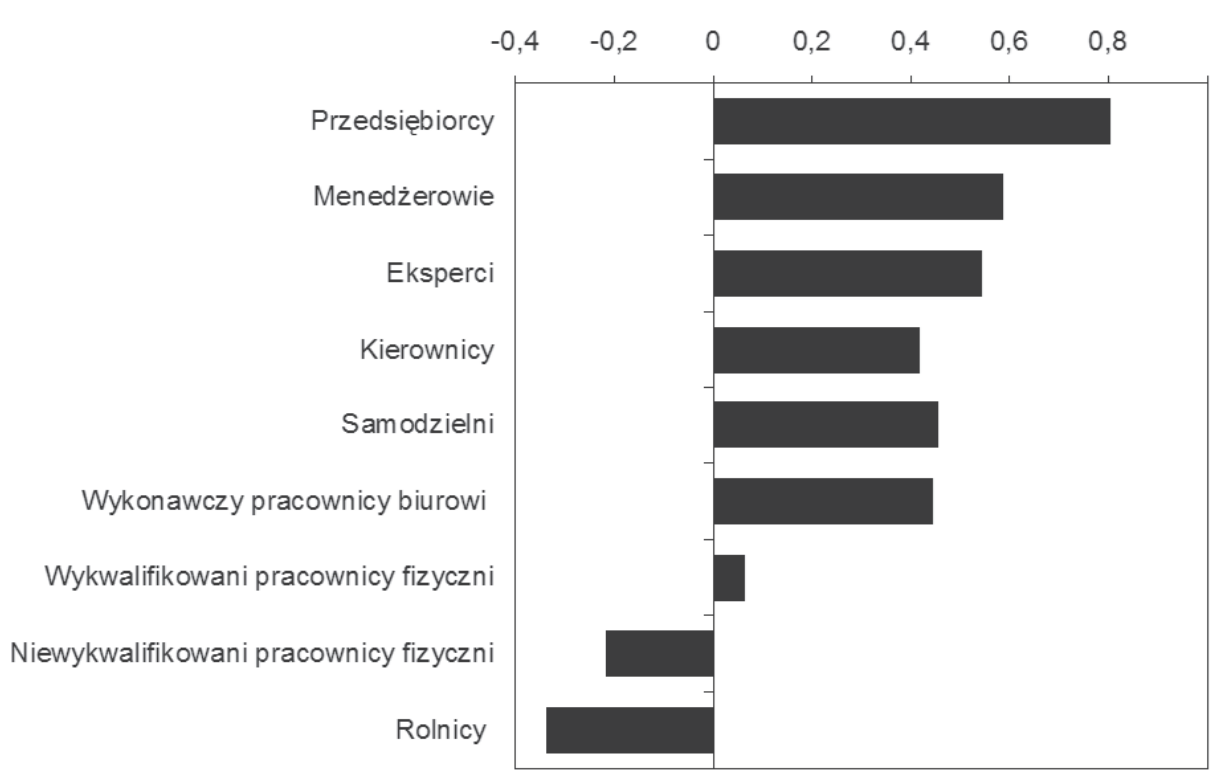

Wykres 1. Średnie wartości skali postaw prorynkowych dla klas społecznych Źródło: POLPAN 2003

W ostatnim wierszu tabeli 3 podajemy stosunek odsetka osób zdecydowanie opowiadających się za tym, aby państwo powinno zapewnić pracę każdemu, kto chce ją podjąć dla dwóch grup: tych, co znajdują się na dole i tych, co znajdują się na górze drabiny społecznej. Stosunek ten wzrasta od 1,05 do 2,21. Przemawia to na rzecz tezy o polaryzacji świadomości społecznej wzdłuż podziałów klasowych.

Tabela 3. Odsetek osób opowiadających się za tym, aby państwo zapewniało pracę każdemu, kto chce ją podjąć w zależności od klas społecznych

\begin{tabular}{|l|c|c|c|c|c|}
\hline \multirow{2}{*}{\multicolumn{1}{|c|}{ Klasy społeczne }} & \multicolumn{5}{|c|}{ Rok } \\
\cline { 2 - 6 } & 1988 & 1993 & 1998 & 2003 & 2008 \\
\cline { 2 - 6 } & \multicolumn{4}{|c|}{$\begin{array}{r}\text { Odsetek osób opowiadających się za tym, aby państwo } \\
\text { zapewniało pracę każdemu, kto chce ją podjąć }\end{array}$} \\
\hline A. Klasy uprzywilejowane & 67,2 & 45,9 & 33,6 & 29,0 & 24,9 \\
\hline $\begin{array}{l}\text { B. Klasy środka drabiny } \\
\text { stratyfikacyjnej }\end{array}$ & 70,6 & 49,1 & 59,4 & 56,7 & 44,2 \\
\hline $\begin{array}{l}\text { C. Klasy dołu drabiny } \\
\text { stratyfikacyjnej }\end{array}$ & 70,9 & 64,9 & 60,2 & 62,1 & 55,1 \\
\hline Ogółem & 70,5 & 53,7 & 58,3 & 53,2 & 46,6 \\
\hline $\begin{array}{l}\text { Stosunek wartości w wierszu C } \\
\text { do wartości w wierszu A }\end{array}$ & 1,05 & 1,41 & 1,79 & 2,14 & 2,21 \\
\hline
\end{tabular}




\section{KONFLIKTY STRUKTURALNE JAKO WYMIAR POLARYZACJI ŚWIA- DOMOŚCI SPOŁECZNEJ}

Cechą procesów społecznych jest ich dwoisty charakter w tym sensie, że ich odbicie w świadomości społecznej są równie ważnym elementem rzeczywistości społecznej, jak ich obiektywne cechy i kształtujące je mechanizmy. Szczególnie ważną sferą potocznej świadomości są napięcia międzygrupowe i konflikty społeczne wywoływane różnego rodzaju podziałami społecznymi. W epoce dawnego systemu społeczno-gospodarczego ideały egalitaryzmu zostały głęboko uwewnętrznione. Po części pod ich wpływem kształtowała się ideologia ruchu „Solidarności” i oczekiwania wobec rzeczywistości społecznej po zmianie systemowej. Tak więc, mimo krytycznej oceny i zdystansowanej postawy wobec socjalizmu, idea równości społecznej pozostaje istotnym punktem odniesienia w ocenie różnorodnych zjawisk społecznych. W tym kontekście jest rzeczą ciekawą, jak są postrzegane i oceniane podziały społeczne, których źródłem są różnice w sferze władzy, bogactwa, charakteru pracy i podległości organizacyjnej. Oczywiście wymienić można wiele innych kryteriów nierówności, ale wskazane powyżej mają charakter szczególny ponieważ identyfikują podstawowe wymiary systemu stratyfikacji społecznej i mają uniwersalny charakter. Uznać można, że subiektywnie odczuwany stopień konfliktowości w odniesieniu do władzy, bogactwa, charakteru pracy i podległości organizacyjnej jest formą uogólnionej oceny stanu stosunków społecznych. Ocena taka jest istotna z punktu widzenia poczucia spójności społecznej oraz legitymizacji panującego ładu społecznego.

Jak wynika z danych zawartych w tabeli 4, porównawcza analiza opinii co do konfliktogennego potencjału głównych źródeł różnic społecznych i wynikających zeń podziałów grupowych dowodzi, że ich hierarchia ważności nie ulega zmianie. W tabeli tej wyróżniliśmy dwa okresy 1988-1993 i 2003-2008. Sfera władzy politycznej oraz kwestie materialne postrzegane są niezmiennie jako najważniejsze źródło podziałów w społeczeństwie polskim. Natomiast czynnikami o relatywnie mniejszej sile sprawczej - jeśli chodzi o zdolność wywoływania konfliktów społecznych - okazują się różnice w charakterze pracy oraz kryterium podziału organizacyjnego tj. podział na kierowników i kierowanych. Przyznawanie nieco dalszego miejsca tego rodzaju konfliktom jest tendencją trwałą.

Znamienne jest, że w miarę upływu czasu (w latach 2003-2008), w odbiorze społecznym słabnie potencjał konfliktogenności każdego z wyróżnionych podziałów społecznych. Po prostu coraz mniej respondentów jest przekonanych o znacznej sile napięć międzygrupowych powodowanych różnicami we władzy, bogactwie, charakterze pracy i roli w organizacji pracy. Badane opinie zmieniają się 
z różną intensywnością zarówno jeśli chodzi o rodzaj konfliktu, jak i zajmowane miejsce w strukturze społecznej. Na poziomie ogółu respondentów - poczucie konfliktowości najbardziej zmniejszyło się w odniesieniu do władzy politycznej. Ranga pozostałych kryteriów także się obniżyła, choć nastąpiło to w wyraźnie mniejszym i dość podobnym stopniu.

Tabela 4. Poczucie konfliktowości na przestrzeni lat:

1988-1993 i 2003-2008

\begin{tabular}{|c|c|c|c|}
\hline & $\begin{array}{c}\text { Odsetek } \\
\text { odpowiedzi } \\
\text { pozytywnych }\end{array}$ & Średnia & $\begin{array}{l}\text { Odchylenie } \\
\text { standardowe }\end{array}$ \\
\hline 1 & 2 & 3 & 4 \\
\hline \multicolumn{4}{|l|}{ A. Percepcja konfliktów w 1988 r. } \\
\hline Biedni - bogaci & 43,5 & 2,43 & 0,81 \\
\hline Pracownicy umysłowi - pracownicy fizyczni & 32,6 & 2,27 & 0,78 \\
\hline Rządzący - rządzeni & 60,0 & 2,86 & 0,84 \\
\hline Kierownicy - podwładni & 37,0 & 2,34 & 0,79 \\
\hline \multicolumn{4}{|l|}{ B. Percepcja konfliktów w 1993 r. } \\
\hline Biedni-bogaci & 60,0 & 2,71 & 0,82 \\
\hline Pracownicy umysłowi - pracownicy fizyczni & 35,3 & 2,30 & 0,78 \\
\hline Rządzący - rządzeni & 81,4 & 3,21 & 0,73 \\
\hline Kierownicy - podwładni & 39,3 & 2,42 & 0,78 \\
\hline \multicolumn{4}{|l|}{ C. Różnica 1993-1988 } \\
\hline Biedni - bogaci & 16,5 & 0,28 & 0,01 \\
\hline Pracownicy umysłowi - pracownicy fizyczni & 2,7 & 0,03 & 0,00 \\
\hline Rządzący - rządzeni & 21,4 & 0,35 & $-0,11$ \\
\hline Kierownicy - podwładni & 2,3 & 0,08 & $-0,01$ \\
\hline \multicolumn{4}{|l|}{ D. Percepcja konfliktów w 2003 r. } \\
\hline Biedni - bogaci & 68,1 & 2,96 & 1,07 \\
\hline Pracownicy umysłowi - pracownicy fizyczni & 43,4 & 2,57 & 1,14 \\
\hline Rządzący - rządzeni & 88,5 & 3,42 & 0,93 \\
\hline Kierownicy - podwładni & 55,7 & 2,81 & 1,17 \\
\hline \multicolumn{4}{|l|}{ E. $\quad$ Percepcja konfliktów w 2008 r. } \\
\hline Biedni - bogaci & 62,2 & 2,72 & 0,81 \\
\hline Pracownicy umysłowi - pracownicy fizyczni & 42,7 & 2,37 & 0,75 \\
\hline Rządzący - rządzeni & 75,5 & 2,97 & 0,76 \\
\hline Kierownicy - podwładni & 56,2 & 2,64 & 0,76 \\
\hline
\end{tabular}


Tabela 4 (cd.)

\begin{tabular}{|l|r|r|c|}
\hline \multicolumn{1}{|c|}{1} & 2 & 3 & 4 \\
\hline F. Różnica 2008-2003 & $-5,9$ & $-0,24$ & $-0,26$ \\
\hline Biedni - bogaci & $-0,7$ & $-0,20$ & $-0,36$ \\
\hline Pracownicy umysłowi - pracownicy fizyczni & $-13,0$ & $-0,45$ & $-0,17$ \\
\hline Rządzący - rządzeni & 0,5 & $-0,17$ & $-0,41$ \\
\hline Kierownicy - podwładni
\end{tabular}

Z punktu widzenia tezy o polaryzacji struktury społecznej najciekawsze jest jednak pytanie, czy zmiany w postrzeganiu konfliktowości są w jakiś szczególny sposób powiązane z pozycją w strukturze klasowej. Oczekiwanie, że taki związek istnieje wynika z psychospołecznego mechanizmu kształtowania się przekonań, u podłoża których leżą swoiste obserwacje i doświadczenia, odrębny system wartości, właściwe pewnym grupom aspiracje i interesy. Pamiętając, że w latach 2003-2008 poczucie konfliktowości w czterech wymiarach zróżnicowania społecznego generalnie zmniejszyło się, warto odnotować szczególne cechy percepcji osób należących do wyróżnionych klas społecznych. Materiału do takiej analizy dostarcza tabela 5. W pierwszej kolumnie tej tabeli umieszczono wartości syntetycznego miernika poczucia konfliktowości. Jest nim skala definiowana jako konstrukt wynikający z analizy czynnikowej. Wyrażona w jednostkach standaryzowanych skala ta określa poziom subiektywnej konfliktowości odczuwanej w kolejnych klasach społecznych względem średniego natężenia w populacji. Analiza kierunku i stopnia odchylenia wartości poszczególnych indeksów od przeciętnego poziomu konfliktowości (przybierającego wartość „0") pozwala uchwycić proces ewentualnej polaryzacji badanej sfery świadomości społecznej. Jest oczywiste, że większa rozbieżność w odczuwaniu konfliktowości pomiędzy określonymi kategoriami respondentów oznacza silniejszą polaryzację świadomości społecznej. Obserwowane w dłuższym przedziale czasu zmiany w sposobie postrzegania podziałów społecznych wiele mówią nie tylko o przemianach potocznej percepcji, ale także o dynamice samej struktury społecznej.

Zacznijmy jednak od poszczególnych wymiarów konflitowości. Przekonanie, że podział ,władza-społeczeństwo" generuje silne konflikty straciło najwięcej zwolenników wśród właścicieli i ekspertów, a następnie menedżerów i kierowników średniego szczebla. Natomiast w najmniejszym stopniu opinia ta uległa zmianie wśród pracowników fizycznych a także samozatrudnionych. Charakterystyczny jest również kierunek zmian opinii o roli podziału według władzy organizacyjnej: zwierzchnicy - podwładni. Przekonanie, że rola tego podziału w tworzeniu 
niechęci międzygrupowych jest istotna - po upływie pięciu lat - staje się częstsze zarówno wśród właścicieli i menedżerów, jak i wśród robotników, a szczególnie wśród niewykwalifikowanych pracowników fizycznych. Jeśli chodzi o konflikty wynikające $\mathrm{z}$ różnic $\mathrm{w}$ charakterze pracy jest znamienne, że wśród pracowników fizycznych przekonanie to utrzymuje się na niezmienionym w ciągu pięciu lat poziomie, podobnie jest wśród menedżerów. Dziwić może fakt, że niezmienność tej opinii cechuje grupy o odmiennym statusie pracowniczym i przeciwstawnej pozycji w strukturze organizacyjnej zakładu pracy. Warto odnotować, że władza organizacyjna jako źródło konfliktów w społeczeństwie zyskała na znaczeniu w grupie kierowników średniego szczebla oraz rolników. W pierwszym przypadku, ze względu na funkcję pełnioną w procesie pracy, jest to w pełni zrozumiałe. Natomiast w wypadku rolników taka ewolucja poglądów jest co najmniej zastanawiająca.

Tabela 5. Średnie wartości poczucia konfliktowości, 2003-2008

\begin{tabular}{|c|c|c|c|c|c|}
\hline \multirow{3}{*}{ Klasa społeczna } & \multirow{3}{*}{$\begin{array}{l}\text { Ogólne poczucie } \\
\text { konfliktowości } \\
\text { w jednostkach } \\
\text { standaryzowanych } \\
\quad(\mu=0, \sigma=1)\end{array}$} & \multicolumn{4}{|c|}{ Poczucie konfiktowości } \\
\hline & & $\begin{array}{l}\text { biedni } \\
\text { - bogaci }\end{array}$ & \begin{tabular}{|c|} 
fizyczni \\
- umysłowi
\end{tabular} & $\begin{array}{c}\text { rządzący } \\
\text { - rządzeni }\end{array}$ & $\begin{array}{l}\text { kierownicy } \\
\text { - podwładni }\end{array}$ \\
\hline & & \multicolumn{4}{|c|}{$\begin{array}{c}\quad \text { średnia ocena konfliktu wg skali: } 4=\text { silny, } \\
3=\text { raczej silny, } 2=\text { raczej słaby, } 1=\text { brak konfliktu }\end{array}$} \\
\hline 1 & 2 & 3 & 4 & 5 & 6 \\
\hline \multicolumn{6}{|c|}{ A. 2003 r. } \\
\hline $\begin{array}{l}\text { Przedsiębiorcy (zatrud- } \\
\text { niający siłę roboczą) }\end{array}$ & 0,104 & 3,02 & 2,60 & 3,44 & 3.00 \\
\hline $\begin{array}{l}\text { Menedżerowie (wyższe } \\
\text { kadry kierownicze) }\end{array}$ & $-0,240$ & 2,80 & 2,42 & 3,31 & 2,53 \\
\hline Eksperci (specjaliści) & $-0,027$ & 2,99 & 2,50 & 3,39 & 2,81 \\
\hline $\begin{array}{l}\text { Kierownicy (bezpośred- } \\
\text { ni kontrolerzy procesu } \\
\text { pracy) }\end{array}$ & $-0,259$ & 2,82 & 2,34 & 3,24 & 2,61 \\
\hline $\begin{array}{l}\text { Samodzielni (pracujący } \\
\text { na własny rachunek) }\end{array}$ & 0,249 & 3,13 & 2,81 & 3,44 & 3,10 \\
\hline $\begin{array}{l}\text { Wykonawczy pracowni- } \\
\text { cy umysłowi }\end{array}$ & 0,037 & 2,96 & 2,66 & 3,53 & 2,71 \\
\hline $\begin{array}{l}\text { Wykwalifikowani pra- } \\
\text { cownicy fizyczni }\end{array}$ & $-0,054$ & 2,97 & 2,47 & 3,50 & 2,67 \\
\hline $\begin{array}{l}\text { Niewykwalifikowani } \\
\text { pracownicy fizyczni }\end{array}$ & 0,001 & 2,98 & 2,61 & 3,27 & 2,90 \\
\hline Rolnicy & 0,119 & 2,92 & 2,69 & 3.33 & 3,18 \\
\hline Wspótczynnik eta ${ }^{2}$ & $0,02^{* *}$ & 0,01 & 0,02 & $0,04^{* *}$ & 0,02 \\
\hline
\end{tabular}


Tabela 5 (cd.)

\begin{tabular}{|l|c|c|c|c|c|}
\hline \multicolumn{1}{|c|}{1} & 2 & 3 & 4 & 5 & 6 \\
\hline \multicolumn{3}{|c|}{ B. 2008 r. } \\
\hline $\begin{array}{l}\text { Przedsiębiorcy (zatrud- } \\
\text { niający siłę roboczą) }\end{array}$ & $-0,409$ & 2,37 & 2,08 & 2,70 & 2,44 \\
\hline $\begin{array}{l}\text { Menedżerowie (wyższe } \\
\text { kadry kierownicze) }\end{array}$ & $-0,174$ & 2,58 & 2,36 & 2,76 & 2,55 \\
\hline Eksperci (specjaliści) & $-0,094$ & 2,72 & 2,25 & 2,92 & 2,57 \\
\hline $\begin{array}{l}\text { Kierownicy (bezpośred- } \\
\text { ni kontrolerzy procesu } \\
\text { pracy) }\end{array}$ & 0,059 & 2,76 & 2,41 & 3,00 & 2,58 \\
\hline $\begin{array}{l}\text { Samodzielni (pracujący } \\
\text { na własny rachunek) }\end{array}$ & $-0,071$ & 2,65 & 2,31 & 3,04 & 2,58 \\
\hline $\begin{array}{l}\text { Wykonawczy pracowni- } \\
\text { cy umysłowi }\end{array}$ & 0,124 & 2,80 & 2,46 & 3,02 & 2,69 \\
\hline $\begin{array}{l}\text { Wykwalifikowani pra- } \\
\text { cownicy fizyczni }\end{array}$ & $-0,026$ & 2,71 & 2,36 & 2,92 & 2,59 \\
\hline $\begin{array}{l}\text { Niewykwalifikowani } \\
\text { pracownicy fizyczni }\end{array}$ & $-0,011$ & 2,72 & 2,42 & 2,96 & 2,58 \\
\hline Rolnicy & 0,121 & 2,79 & 2,52 & 2,98 & 2,77 \\
\hline Wspótczynnik eta ${ }^{2}$ & $0,02^{*}$ & 0,01 & 0,02 & $0,02^{*}$ & 0,02 \\
\hline
\end{tabular}

${ }^{*} \mathrm{p}<0,05 ;{ }^{* *} \mathrm{p}<0,10$

Kwestie materialne są istotną siłą napędową dla różnego typu aktywności życiowej, tak więc z oczywistych powodów różnice - były zawsze szczególnie widoczne. Dane pokazują jednakże, iż poziom konfliktowości wywoływanej różnicami materialnymi ustępuje podziałowi o charakterze politycznym: na rządzących i resztę społeczeństwa (ranga według średniej ocen to odpowiednio 2,72 oraz 2,97 - dla roku 2008 oraz 2,96 i 3,46 w roku 2003). Chociaż obiektywnie mierzone rozwarstwienie w sferze materialnej pogłębia się, proporcja osób przekonanych o silnej konfliktowości różnic materialnych zmniejsza się we wszystkich klasach. Najbardziej jest to widoczne w trzech kategoriach - wśród samozatrudnionych, właścicieli i menedżerów. Tendencja ta współgra z faktem, że wymienione grupy cieszą się dobrą kondycją materialną, a ich przedstawicieli zaliczyć można do grona wygranych w transformacji. Dla porównania dodajmy, że poglądy robotników wykwalifikowanych pozostają w tej kwestii niemal stabilne. Obserwowane zmiany w postrzeganiu konfliktów sygnalizują, iż nastąpiło pewne obniżenie progu wrażliwości na niepożądane skutki różnic i uwarstwienia społecznego. Można się zastanawiać czego jest to przejawem, czy coraz lepszego 
przystosowania do zmieniających się warunków pracy i życia w nowym ustroju i aprobaty jego zmiany czy też wskaźnikiem realnego i istotnego polepszenia własnej kondycji społeczno-ekonomicznej.

Oto co wynika $\mathrm{z}$ danych na temat międzyklasowych różnic $\mathrm{w}$ odczuwaniu konfliktowości podziałów społecznych:

W roku 2003 - relatywnie mniejsze poczucie konfliktowości (poniżej średniej) mieli menedżerowie i kierownicy oraz w mniej znacznym stopniu także eksperci. Natomiast najbardziej konfliktowość odczuwali (powyżej średniego poziomu) pracujący na własny rachunek i rolnicy. Ciekawe jest, że świadomość napięć międzygrupowych wśród pracowników fizycznych nie odbiegała znacząco od poziomu średniego. Ze względu na niewielką skalę rozziewu w poziomie odczuwanej konfliktowości w 2003 r. mówić można co najwyżej o słabej tendencji do polaryzacji tej sfery świadomości społecznej.

Z kolei w roku 2008 zróżnicowanie percepcji konfliktowości względem klasy społecznej uległo niełatwym do interpretacji zmianom. Najbardziej charakterystyczna różnica dotyczy „Zwycięzców” transformacji. Wyjątkiem są eksperci, których poglądy na temat ostrości podziałów i barier społecznych są raczej ustabilizowane. W wypadku innych kategorii zmiany opinii nie są bynajmniej jednokierunkowe. Właściciele okazali się tymi respondentami, których poczucie ostrości konfliktów społecznych w porównaniu z rokiem 2003 znacznie zmalało i w roku 2008 było najsłabsze. Duża zmiana dokonała się też w świadomości osób pracujących na własny rachunek. W ciągu kolejnych lat funkcjonowania gospodarki liberalnej ich odczucie konfliktowości radykalnie osłabło zbliżając się do przeciętnego poziomu. Trudno rozstrzygnąć, co kryje się za tą zmianą - czy jest to wynik akceptacji nowych reguł gry, czy efekt uzyskania niezależności i powodzenia materialnego. W przeciwnym kierunku zmieniała się wizja podziałów społecznych wśród menedżerów i kierowników średniego szczebla. Szczególnie w tej drugiej kategorii - prawdopodobnie pod wpływem doświadczeń płynących z zanurzenia w praktyce gospodarczej - wrażliwość na skutki różnic społecznych znacznie wzrosła. Poczucie konfliktowości wzrosło także wśród techników i personelu biurowego. Gdyby wiązać tę zmianę z osobistymi doświadczeniami, przyczyny wyostrzenia wizji konfliktów w tej grupie społecznej można by się doszukiwać w procesach ogólniejszej natury - obniżeniu rangi zrutynizowanej pracy umysłowej i generalnie w niskim statusie pracy urzędniczej.

Dużym zaskoczeniem jest znaczna stabilizacja sposobu myślenia o różnicach i podziałach społecznych w przypadku pracowników fizycznych zarówno wykwalifikowanych, jak pozbawionych kwalifikacji. Kategorie te stanowiły trzon tradycyjnej klasy robotniczej, klasy fundamentalnej w systemie społecznopolitycznym minionego ustroju. Żywotne interesy tego segmentu społecznego 
- nie tylko na poziomie ideologii - ściśle wiązały się z kwestią nierówności społecznych i ideałami sprawiedliwości. Stąd płynie oczekiwanie, że to w pierwszym rzędzie robotnicy będą najbardziej krytycznie oceniać przejawy nierówności, przypisując im wysoką konfliktogenność. Tymczasem mierzone na ogólnej skali konfliktowości przekonania robotników sytuują się nawet nieco poniżej wartości przeciętnych. Uzyskane $\mathrm{w}$ badaniach dane nie potwierdziły zatem oczekiwań, sygnalizując tym samym, że ważna z punktu widzenia tradycyjnie definiowanej tożsamości klasowej sfera percepcji utraciła znaczenie. Dlaczego tak się dzieje? Być może powodem jest znaczne zróżnicowanie warunków pracy robotników, ich przestrzenna i organizacyjna atomizacja oraz niepewność zatrudnienia $\mathrm{w}$ liberalnej gospodarce rynkowej ${ }^{4}$. Jest zatem prawdopodobne, że zmiany wynikające z segmentacji rynku pracy i przeformułowania zasad jego funkcjonowania wymusiły przyswojenie przez pracowników fizycznych ,indywidualnych strategii przetrwania", co zmieniło ich optykę postrzegania stosunków społecznych.

Gdybyśmy mieli formułować tezę o polaryzacji potocznej wizji konfliktowości struktury społecznej, jako opozycyjne segmenty należałoby wskazać z jednej strony właścicieli i menedżerów oraz w mniejszym stopniu - ekspertów i samozatrudnionych, a z drugiej strony - rutynowych pracowników technicznych i biurowych oraz pracowników handlu i usług. Jest znamienne, że robotnicy, a więc pracownicy fizyczni bez względu na poziom kwalifikacji z tego bipolarnego schematu percepcji unikają.

\section{PODSUMOWANIE}

Gdy analizujemy podstawowe wymiary stratyfikacji społecznej - formalne wykształcenie, pozycję zawodową i zarobki - okazuje się, że różnice klasowe są znaczne i nie usprawiedliwiają antyklasowej retoryki. Jednakże klasy społeczne nie są redukowalne do prostego układu hierarchicznego w tych trzech wymiarach. Relacje między klasami są złożone i zmieniają się w czasie. W artykule tym przedstawiliśmy dwa schematy klasowe skonstruowane tak, aby pierwszy z nich odpowiadał zasadniczym cechom ustroju socjalistycznego a drugi - zasadniczym cechom ustroju po transformacji postkomunistycznej. Pomimo że schematy te różnią się w sposób istotny, dane uzyskane w badaniach POLPAN wskazują, że klasy społeczne typowe dla okresu socjalizmu w wielkim stopniu wpływają na przejścia do określonych klas typowych dla okresu postkomunistycznego.

\footnotetext{
${ }^{4}$ Por. Janicka (2007).
} 
Klasowe różnice ujawniają się zresztą nie tylko w obiektywnych miarach położenia społecznego - takich, jak formalne wykształcenie, pozycja zawodowa czy zarobki. Ujawniają się one w wymiarze psychologicznym, zwłaszcza w odniesieniu do poglądów dotyczących podstawowych zasad funkcjonowania kapitalizmu. $\mathrm{Ci}$, co są „na górze” i którym dobrze powodzi się w systemie rynkowym popierają go w znacznym stopniu. Ale ci, którzy sobie gorzej radzą - oponują przeciw wolnemu rynkowi.

W strukturze społecznej - której emanacją jest struktura klasowa - mogą powstawać napięcia z tego powodu, że jedne grupy społeczne lepiej, a inne gorzej dostosowują się do zmieniających się warunków. Używając metaforycznego języka wprowadzonego przez nas wcześniej można powiedzieć, że duże różnice między klasami w zakresie poglądów na funkcjonowanie podstawowych instytucji kapitalizmu znamionują pęknięcia w strukturze społecznej; ponadto przedstawiono dowody, że pęknięć tych jest stosunkowo dużo, a prawie wszystkie nakładają się na siebie, oddzielając daleko zwycięzców i przegranych postkomunistycznej transformacji. Ze względu na to, iż rysy przebiegają wzdłuż jednej linii podziału, mówić można o pękniętej strukturze społeczeństwa polskiego, częściowo w wyniku polaryzacji. Utrzymujemy tę tezę, sformułowaną kilka lat temu i ciągle potwierdzaną przez dane empiryczne.

\section{BIBLIOGRAFIA}

Domański H., Sawiński Z., Słomczyński K.M. (2007), Nowa klasyfikacja i skale zawodów. Socjologiczne wskaźniki pozycji społecznej w Polsce, Warszawa: Wydawnictwo IFiS PAN.

Janicka K. (2007), Formy zatrudnienia a cechy sytuacji pracy. Niektóre parametry i tendencje zmian rynku pracy w Polsce, [w:] K.M. Słomczyński (red.), Kariera i sukces. Analizy socjologiczne, Zielona Góra-Warszawa: Uniwersytet Zieonogórski, Instytut Filozofii i Socjologii PAN.

Janicka K. (2012), Podziały w społeczeństwie polskim: źródta i siła konfliktów społecznych w opinii Lubuszan, [w:] Z. Leszkowicz-Baczyńska, D. Szaban (red.), Lubuszanie w pierwszej dekadzie XXI wieku. Portret socjologiczny, Zielona Góra: Lubuskie Towarzystwo Naukowe.

Słomczyński K.M., Janicka K. (2005), Pęknięta struktura społeczna, [w:] M. Jarosz (red.), Polska. Ale jaka? Warszawa: Oficyna Naukowa.

Słomczyński K.M., Janicka K.(2008), Polarized Social-Class Structure: On the Matthew Effect and Increasing Inequality „Polish Sociological Review”, no. 4.

Słomczyński K.M., Janicka K., Shabad G., Tomescu-Dubrow I. (2007), Changes in Class Structure in Poland, 1988-2003: Crystallization of the Winners-Losers' Divide, „Polish Sociological Review", no. 157.

Słomczyński, K.M., Tomescu-Dubrow I. (2008), Systemowe zmiany w strukturze klasowej a ruchliwość społeczna, [w:] H. Domański (red.), Zmiany stratyfikacji społecznej w Polsce, Warszawa: Wydawnictwo IFiS PAN. 
Krystyna Janicka, Kazimierz M. Słomczyński

\title{
FROM INEQUALITY TO POLARISATION: CLASS STRUCTURE DIVIDE AND THE DIFFERENCES IN SOCIAL AND POLITICAL ATTITUDES
}

\begin{abstract}
(Summary)
The paper presents the dynamics of class structure transformation since the year 1988 focusing on the ongoing stratification of formal education, occupational status and the per capita income. Distance separating wealthy business-owners from the less fortunate keeps growing as a result of wealth concentration on the one hand and continuous pauperization on the other. These processes are reflected in the so-called St. Matthew effect. It - roughly speaking - predicts that those who have much will eventually have more while those who have little will have even less. The growing social inequality in Poland occurs in the class-structural context. It is worthwhile to know whether the St. Matthew effect is also instrumental in generating opposite social and political orientations. To answer this question we examine the data of the Polish Panel Survey 1988-2008 (POLPAN). Our analysis demonstrates that location of individuals in the social-class structure influences their attitudes toward market economy and their perception of social conflicts.
\end{abstract}

